\title{
Our New President
}

\section{Mr. M. K. Mittal}

(b 1941), B.Sc., B. Tech. (Hons.), FIE, CE, Director (Engg., R\&D), BHEL House, Siri Fort, New Delhi - 110049

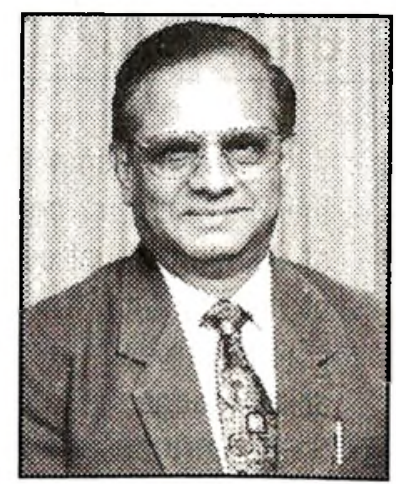

Shri M. K. Mittal is a mechanical engineering graduate from IIT, Kharagpur having passed out in the year 1963. Joining BHEL Plant in 1966 at Hardwar, Mr. Mittal has a long and unmatched experience for establishing Turbine Industry. Under his stewardship, the country's first $100 \mathrm{MW}$ Steam Turbine was tested and also the country's 200 MW Steam Turbine was handed over by the then Prime Minister to the Nation. Under technical collaboration with M/s. Siemens, Mr. Mittal successfully manufactured the first $500 \mathrm{MW}$ Steam Turbine and later a number of such capacity Turbines including Hydro were produced thereby contributing towards the installed capacity of the country.

He was selected to head one of the country's key Power Sector Zone, viz., the Eastern Region at Calcutta and was responsible for commissioning of Farakka $500 \mathrm{MW}$ and Kolaghat $210 \mathrm{MW}$ Power Projects. With his efforts, it was for the first time that West Bengal produced surplus power and exported the same to other States. In 1993, he became the Chief Executive of the Hardwar Plant which under his able leadership registered a turnover from Rs. 513 crores in 1994-95 to Rs. 687 crores in 1996-97. Entering into a collaboration agreement with $\mathrm{M} / \mathrm{s}$. Oto Melara, Italy, he established the manufacturing facilities for Super Rapid Gun Mounts for Defence. He also had a short stint at the Central Foundry Forge plant (CFFP) where he took up the challenge of manufacture and supply of Turret Castings for T-72 Tank for Defence. Similarly, this Unit developed Special Steel Forgings for Space applications in PSLV and also for Nuclear and other strategic applications during his tenure.

As a Member on the Board of Directors of BHEL, Mr. Mittal has provided a fresh impetus to the R\&D activity of the company including WRI, viz., the country's. only integrated Gasification Combined Cycle demonstration project producing coal gas is stated to run the Gas Turbine and down-stream Combined Cycle Plant. He is presently engaged in the development of 5 MVA Superconducting Generator. He has also been instrumental in successful installation of the country's first $200 \mathrm{KW}$ Fuel Cell and commissioning at BHEL's R\&D Unit at Hyderabad. Fuel Cell has so far logged 2.5 MW hours. In addition to his present assignment in BHEL, he has also been appointed Chairman cum Managing Director of Cement Corporation of India Limited, a Public Sector Enterprise. Based on his vast experience and knowledge base, he represents in various Committees of National importance. Mr. Mittal is distinguished Member of NPL Advisory Committee, member of R\&D Advisory Committee of Ministry of Non-Conventional Energy Source (MNES), member of Center of Wind Energy Technology Steering Committee of MNES \& member of high powered CII-TIFAC action team on Energy. Mr. Mittal is Chairman of Working Group on Manufacturing Technology of Deptt. Of Electronics (DOE) and Chairman of Indian Value Engineering Society (INVEST), North Zone Council. He is Chairman of Mechanical Engineering Division Council of Bureau of Indian Standards (BIS). Mr. Mittal also represents in the Governing Council of Center for Electronics Design \& Technology of India. He has taken over as the President of Indian Institute of Welding recently. 